\title{
Skin Squamous Cell Carcinoma or Other Skin Carcinomas Pathologic Distant Metastasis TNM Finding v7
}

National Cancer Institute

\section{Source}

National Cancer Institute. Skin Squamous Cell Carcinoma or Other Skin Carcinomas

Pathologic Distant Metastasis TNM Finding v7. NCI Thesaurus. Code C88491.

A pathologic finding about one or more characteristics of skin squamous cell carcinoma or other skin carcinomas, following the rules of the TNM AJCC V7 classification system as they pertain to distant metastases. (from AJCC 7th Ed.) 